\title{
SPEAK UP YOUR STUDENTS WITH MIRROR, HANDS AND EYES
}

\author{
Nur Effendi \\ Department of English Teaching \\ Faculty of Letters and Arts Education IKIP PGRI Madiun \\ neweffendi@gmail.com
}

\begin{abstract}
Mirror, Hands and Eyes is a technique to teach speaking which use mimic in it. This research has purposes to describe how the implementation of Mirror, Hands and Eyes, and to know the advantages and disadvantages of the implementation of Mirror, Hands and Eyes in teaching speaking. This is descriptive qualitative research. The researcher takes three sources of the data, social situation, informant, and document. The sample is using purposive sampling. Observation, interview and documentation are the technique used by the researcher to collect the data. Theoretical and methodological triangulation used by the researcher to measure the valid data. The techniques of analyzing data are compiling, disassembling, reassembling, interpreting, and concluding.The advantages of this technique are increase the students' speaking skill, increase the students' enthusiast, easily follow the correct pronunciation, lock the students' focus. The disadvantages are the technique disallow the students build new words, and the lack of vocabulary makes the students face the difficulties to make sentences. It can be concluded by the theory of Panesso and Brown with little modification to make students speak up that show the implementation of Mirror, Hands and Eyes works in chronological ways with pre-activity, whilst activity, and post activity inside.
\end{abstract}

Keywords: Mirror, Hands and Eyes; Technique; Speaking

\section{Introduction}

The goal of studying foreign language is having an ability to speak the language, this is one of the goal. Nunan (in Septiana, 2014: 2) states that "Speaking is the productive aural/oral skills. It consists of producing systematic verbal utterance to convey meaning." That is what speaking all about, express people's thought by producing verbal language and it is spoken through its mouth. So, does it work already in school area, when teacher and students learning foreign language in class? Do they have meaningful conversation?

Teaching speaking ideally involves the role of both teachers and students. The role of teachers is to teach and make an attractive teaching speaking to make students speak up, when students respond interactively with English, here both role of teachers and students can be seen, and teaching speaking as a foreign language can be called as ideal. Brown 
(2000: 267) states that "In the classroom, even relatively unidirectional types of spoken language input (speeches, lectures, etc.) are often followed or preceded by various forms of oral production on the part of students." It means that there should be an interaction of both teachers and students, and it is naturally produced. Teaching speaking should be looks more natural, which mean there is no shy students who afraid to speak up, less students speak with mother language but English, there is no students who dominantly pick by teacher all the time. So everything must get their part, involving students to speak in two ways conversation among the other students and also teachers, or just simply unidirectional types of spoken language.

The thing is, the real condition of teaching speaking is not as simply ideal as above. Students sometimes preceded the lesson with their mother language, while ideally it should be more English than native language. There are so many factors to make teaching speaking hard for some, even for teachers, native language and the environment are one of them. Brown (2000: 65) states that "It almost goes without saying that the native language of every learner is an extremely significant factor in the acquisition of new language." It means that Indonesian language is one of the cause to make students hard to learn English. Obviously, students mostly speak with native language rather than speak with English. They are afraid to try and it is worst if teachers respond in the same way, no matter what the students said, teacher have to answer any single thoughts of the students with English, make them familiar with it. Some passive students even prefer to be the silent, they won't try to speak English. If this condition continuously happens without any solution, teaching speaking will end with nothing.

Teachers sometimes face a big problem with the students in teaching speaking. Teachers hard to find the solution of students who won't talk or say anything, or students who should work in group end up with chatting in their own language. Or even, teachers can be the main problem why such a teaching speaking activity won't work, for example, teachers ask the students to speak in English while teacher himself rarely use English when he is speaking. Some teachers might have difficulty in managing the class and mostly they blame their students for its chaos. Westwood (2004: 54) states that "It is important to point out that teachers tend to blame students themselves, or their 
socio-cultural and family backgrounds for the learning difficulties." As Westwood states, it seems that teachers are not evaluate themselves and fix what need to be fix. The problem might be came from the teachers not the students.

Not only the teacher, students also have various problems in teaching and learning activity. Lack of motivation is one of their problems. In teaching speaking which demand students to speak actively, some of them prefer to be passive because they may too afraid to try, this happen because no one motivate them, with complement even for small talk. If such school has such a condition that the students mostly passive in one class, it will effect to the other students and decrease their confident. National Academy of Science (2004: 97) states that "School climate refers to the values, norms, beliefs, and sentiments associated with routine practices and social interaction in schools." So, if the whole students are passive, it will make a routine atmosphere that needs to be solve.

By those reasons above, to manage passive students who are still afraid to speak because the lack of motivation, the researcher wanted to see how well the Mirror, Hands and Eyes applied for eight grade students to teach speaking. That way, the researcher will able to describe the whole learning process.

\section{Theoretical Framework}

The theories are mainly talk about teaching technique that useful for teaching speaking, here the researcher uses Mirror, Hands and Eyes as the technique to teach speaking. According to Pedersen (in Szott and Molitoris, 2010: 6) "Lessons that engage students in seeing, hearing, doing, speaking, and feeling ... while they're having lots fun." It means all the activity that involve human senses like seeing and hearing, also speaking and feeling will have more fun. Because Mirror, Hands and Eyes is one of Whole Brain Teaching's technique which demand the students to see and do the gestures, hear the voices, and also speak the words, it is fit to Pederson explanation.

In the book itself, Biffle said that this is powerful students' engager. According to Biffle (2013: 77) "Mirror, Hands and Eyes is a powerful student engager which demand the students to follow the gestures and mimic the words." It means that Mirror, Hands and Eyes is a technique to engage students by follow the gestures and mimic the words.So, Mirror, Hands and Eyes is technique that engage students' hearing, 
seeing and speaking to promote pronunciation and intonation for students' speaking skill.

\subsection{The Characteristic of Mirror,} Hands and Eyes

Mirror, Hands and Eyes mostly used gestures and imitation, Biffle (2013: 77) divides the characteristic of Mirror, Hands, and Eyes by the gestures. McNeill (in Kelly et al., 2008: 1) states "focusing on language production, was the first to argue that gesture and speech make up a single, integrated system of meaning expression.” It means gesture will work hand in hand with speech and automatically be a system of meaning expression. Biffle (2013: 77) classify the gestures as follow:

\section{a. Casual}

This is the most general gesture. Casual is kind of gesture that we used naturally when we are speaking. Everyone has their own unique gesture when they are speaking, it won't be the same one another.

b. Graphic
More specific, graphic allow you to match the gesture exactly the same with what you are saying. Biffle has given us some example, like, move your fingers in the air when you say "walking", or if you want to explain about big problem then just scratch your head as a gestures.

By using creativity, graphic is the easiest gesture to implement. Sync what you are saying with gestures, and ask the students to mirror it.

c. Memory

This gesture is how you pretending to be what you want to do. Memory, the third gesture which allow you to gesture what you do even more specific than graphic. For example, cross your arms to make multiplication, or push your hand for a "stop" signal.

In conclusion, Mirror, Hands and Eyes can work with only one or even combine all the characteristic above. It depends on the materials that teachers choose to teach with, and also grade where the teachers teach at. 


\subsection{The Procedure of Mirror, Hands} and Eyes

Mirror, Hands and Eyes has the stage to make it works. Biffle (2013: 77) has clearly scripted the example of Mirror, Hands, and Eyes done by one of the teacher name Ms. Maestra. Here are the script that represent the stage of Mirror, Hands and Eyes.

\begin{tabular}{|c|c|}
\hline CRIPT & MIRROR \\
\hline Teacher & Class! \\
\hline Students & Yes! \\
\hline Teacher & $\begin{array}{l}\text { Here is a simple, new, } \\
\text { fun learning technique. } \\
\text { When I say "mirror," } \\
\text { you say "mirror" and } \\
\text { pick up your hands, } \\
\text { ready to mirror my } \\
\text { gestures. Mirror! }\end{array}$ \\
\hline Students & $\begin{array}{l}\text { Mirror! (Students hold } \\
\text { their hands in the air.) }\end{array}$ \\
\hline Teacher & $\begin{array}{l}\text { Great job, but let's do } \\
\text { it a little faster and } \\
\text { maybe you'll get a } \\
\text { Smilie. (very quickly) } \\
\text { Mirror! }\end{array}$ \\
\hline Students & $\begin{array}{l}\text { Mirror! (Students } \\
\text { quickly hold their } \\
\text { hands in the air.) }\end{array}$ \\
\hline Teacher & $\begin{array}{l}\text { Fantastic! (Walking to } \\
\text { the board. Making a } \\
\text { mark on the Smile side } \\
\text { of the Scoreboard.) } \\
\text { Hold it! Hold it! } \\
\text { (Rapidly pointing to } \\
\text { her class.) }\end{array}$ \\
\hline Students & $\begin{array}{l}\text { (Clapping their hands } \\
\text { loudly.) Oh yeah! }\end{array}$ \\
\hline Teacher & Good job. Mirror! \\
\hline Students & Mirror! \\
\hline Teacher & $\begin{array}{l}\text { Now, mirror my } \\
\text { gestures. Today we are } \\
\text { going to talk about a }\end{array}$ \\
\hline
\end{tabular}

great big problem (spreading her arms out wide... students mirror this gesture) but we're going to break it down into little pieces (holding her fingers close together... students mirror this gesture.) Tell you neighbor what I said... using my gestures! Teach!

Students : Okay! (Students use the teacher's gestures to teach their neighbors the teacher's points.)

In conclusion, Mirror, Hands and Eyes has very simple ways to be done. According to script above, "Mirror" becomes the first trigger to make students pay attention. By saying Mirror, students pick their hands and ready to imitate the teachers. It is also follow by gestures of their hands. According to Qian (2012: 2206) "following English tapes and imitating sentences will be effective way to improve pronunciation and intonation." It means that Mirror, Hands and Eyes is a useful technique that focuses on students' attention, pronunciation an also intonation. According to teaching script from Ms. Maestra above, the researcher tries to elaborate the procedure of Mirror, Hands and Eyes as below:

a. Teachers say "Mirror" and pick the hands up follow by the 
students who also say "Mirror" and also pick their hands up.

b. Afterward, teachers say anything that correlate with materials which will be repeat by the students. Teacher may add with gesture which relevant with what they say.

c. The last one, after the students repeat from the teachers, the students have to do in pair with their friend. They in turn do the Mirror, Hands and Eyes.

While Panesso (2012: 31) illustrates her main activity using Mirror, Hands and Eyes as below:

\begin{tabular}{|c|c|}
\hline Activity & Comment \\
\hline $\begin{array}{l}\text { Students will be } \\
\text { asked information } \\
\text { about their } \\
\text { hobbies. } \\
\text { Ex: They will be } \\
\text { asked what they } \\
\text { usually do on } \\
\text { weekends or } \\
\text { vacation. }\end{array}$ & $\begin{array}{l}\text { The principle of } \\
\text { hands and eyes } \\
\text { will be used since } \\
\text { the facilitator will } \\
\text { give instructions } \\
\text { to fulfill the } \\
\text { activity. } \\
\text { *Having this kind } \\
\text { of questions will } \\
\text { most likely to get } \\
\text { students out of } \\
\text { control, so if this } \\
\text { happens, we will } \\
\text { make use of the } \\
\text { principle Class- }\end{array}$ \\
\hline $\begin{array}{l}\text { According to their } \\
\text { answers, } \\
\text { flashcards } \\
\text { containing actions } \\
\text { (Swimming, } \\
\text { running, eating, } \\
\text { singing, writing } \\
\text { and jumping) will } \\
\text { be shown to }\end{array}$ & $\begin{array}{l}\text { The principle } \\
\text { Mirror will be } \\
\text { used. } \\
\text { After the } \\
\text { facilitator mimes }\end{array}$ \\
\hline
\end{tabular}

\begin{tabular}{|c|c|}
\hline $\begin{array}{l}\text { Students. They'll } \\
\text { first listen to the } \\
\text { pronunciation and } \\
\text { then, the facilitator } \\
\text { will check if they } \\
\text { identify the } \\
\text { actions by not } \\
\text { having a sequence } \\
\text { showing them. } \\
\text { After that, } \\
\text { Students will } \\
\text { mime each action } \\
\text { after the } \\
\text { facilitator. }\end{array}$ & $\begin{array}{l}\text { an action Students } \\
\text { will do the same. } \\
\text { Ex: If she jumps, } \\
\text { she will start } \\
\text { jumping and will } \\
\text { say MIRROR and } \\
\text { Students will say } \\
\text { MIRROR and start } \\
\text { jumping and } \\
\text { saying JUMP until } \\
\text { the facilitator says } \\
\text { Ok. }\end{array}$ \\
\hline
\end{tabular}

Panesso (2012: 31)

In conclusion, Mirror, Hands and Eyes will work in chronological sequences as above. Teachers say "mirror" to start the activity of mimicking, say anything with gestures which will be repeated by the students, and students do in pair to do Mirror, Hands and Eyes.

\section{Research Methodology}

This research is simply done by a simple technical process which covered place and time, research design, source of data, data collection, research procedure, and data validation.

The research held at SMPN 1 Takeran in the middle of the semester. This research is a descriptive qualitative research. This descriptive research will describe how the implementation of Mirror, Hands and Eyes and to know the advantages and disadvantages of 
implementation of Mirror, Hands and Eyes in teaching speaking to the eight grade of SMPN Takeran Magetan in schooling year 2014/2015.

The source of data of this study will be the students of eight grade of SMPN 1 Takeran Magetan. Based on Yin (2011: 51), "A source of data-in many cases a fieldwork setting (where are you going to get the data that are to be collected?)." It means that the researcher needs to decide the place where it can be the source of the data.Those students of eight grade will become subject of observation's activity. The whole data originally takes from the phenomenon that happen naturally, and the total population of eight grade students of SMPN 1 Takeran Magetan is 140 students.

There are some sample techniques in qualitative research. The researcher uses purposive sampling in this research. According to Fraenkel and Wallen (2012: 100) "Purposive sampling is different from convenience sampling in that researcher use their judgment to select a sample which they believe, based on prior information, will provide the data they need." It means that the researcher chooses the sample which is relevant to the researcher's believe that provide what the researcher needs to back up the research.In this research, the researcher chooses the eighth grade students of SMPN 1 Takeran Magetan. The researcher chooses $8 \mathrm{~A}$ as the sample because the students have various intelligence level which close enough to represent the whole population, this class has 20 total of the students who will be the sample of research.

There are some ways to collect the data to ensure all the activities recorded into a systematic document. The researcher uses observation, interview and also documentation.

Data validation is the phase to validate all the data use in the research. The process of validation is by checking the data as a proof or substantion that the data has reliable sources.Triangulation will be used as a technique of data validation in this research.Based on Mackey and Gass (2005: 181), there are three types of triangulation.

"Different types of triangulation have been identified, including theoretical triangulation (using multiple perspectives to analyze the same set of data, investigator triangulation (using multiple observer or interviewer, etc), and methodological triangulation (using different measures of research methods to investigate a particular phenomenon."

To get reliable and valid data, the cross-checking will be based on the 
source, which is result of observation, interview and documentation. This research also used theoretical and methodological to run the data validation.

\section{Result of the Research and Discussion}

\subsection{The implementation of Mirror,} Hands and Eyes

In this research, the researcher uses Mirror, Hands and Eyes as the technique to overcome the problem of the students, especially in speaking skill. Mirror, Hands and Eyes has purposes to make the students repeat the word in fun way with gestures, in the same time it also controls the focus of the students. The complete data related to the implementation of Mirror, Hands and Eyes technique taken from the result of observation, interview, and documentation that have been done on April 30th, 2015.

There are three main activities that are done by the teacher in the implementation of Mirror, Hands and Eyes in Teaching Speaking to the Eight Grade Students of SMPN 1 Takeran Magetan in Schooling Year 2014/2015. There are pre activity, whilst activity, and post activity.
In the pre activity, the teacher gives some kind of opening before go to the whilst-activity. The teacher do some chit chat with the students, the simple one like greeting, then the class begins by perform pray. After that, teacher check the attendance list, reviewing the last material and remind the students about Classroom Rules, and begin the class with showing one picture that have to be describe by the students.

In the whilst-activity, the teacher gives an easy way to describe things and people by using adjectives, students can use OSASCOM as the guideline. Then teacher now gives an example of Mirror, Hands and Eyes. Then the teacher asks the class to make a group consist of five students. One of the students will be the leader or group representative. One student gives one description, and the group representative must guess correctly what is in the picture. By using Mirror, group representative leads the process followed by the rest of students. The teacher monitor if there is a wrong pronunciation.

In post activity, teacher with the students review the material that have been learned by giving questions to remind them, asks their difficulties during the learning process and give 
them a feedback, after that, a home work given for the students to keep them remember about descriptive text, both teacher and the students pray together and teacher greet the class to end the session.

\subsection{The advantages and disadvantages} of the implementation of Mirror, Hands and Eyes

There are some advantages and disadvantages of the implementation of Mirror, Hands and Eyes in Teaching Speaking to the Eight Grade Students of SMPN 1 Takeran Magetan in Schooling Year 2014/2015.

The advantages are firstly, based on the result of interview, both English teacher and students says that Mirror, Hands and Eyes is a technique that have a lot of fun, students says that they enjoy the class and did not feel bored. Secondly, this technique demands the students to follow the words correctly by pronunciation. Thirdly, in the same time this technique also controls the students focus.

The disadvantages are, this technique has total control of what students have to say. This technique do not allow the students to improvise by making new words. Without teacher's assistance, this technique can make the students pronounce the wrong word, so teacher has to be there and monitor the whole words spoken.

\section{Conclusion}

After analyzed the data, the researcher wants to make some conclusions related to the implementation of Mirror, Hands and Eyes in teaching speaking to the eight grade students of SMPN 1 Takeran Magetan in schooling year 2014/2015. The conclusions related to the problem in previous chapter includes:

\subsection{The implementation of Mirror,} Hands and Eyes

The implementation of Mirror, Hands and Eyes in teaching speaking to the eight grade students of SMPN 1 Takeran Magetan in schooling year 2014/2015 are suitable with lesson plan (RPP), learning scenario, checklist observation, and the theory of Panesso and Brown with little modification of activities from the teacher to make the students speak up. Based on the discussion in Chapter V, the researcher concludes that the implementation of the technique has three activities including pre-activity, whilst-activity and postactivity. 


\subsection{The advantages and disadvantages}

of the implementation of Mirror,

Hands and Eyes

a. The Advantages

The researcher has said that there are some advantages of the implementation of Mirror, Hands and Eyes in teaching speaking to the eight grade students of SMPN 1 Takeran Magetan in schooling year 2014/2015, they are:

1) Mirror, Hands and Eyes in teaching speaking makes the students enthusiast and have a lot of fun during the class.

2) Mirror in teaching speaking makes students easy to follow the exact word with correct pronunciation.

3) Hands and Eyes makes students give more attention and focus on the teacher.

b. The Disadvantages

Beside the advantages, there are some disadvantages of Mirror, Hands and Eyes in teaching speaking of descriptive text, they are:

1) Mirror, Hands and Eyes disallow the students to build new words but repeat.

2) The students get the difficulties in making a sentence because they have less vocabulary.

\section{References}

Biffle, Christopher. (2013). Whole Brain Teaching for Challenging Kids. New York: McGraw-Hill.

Brown, H. Douglas. (2000). Teaching by Principles An Interactive Approach to Language Pedagogy Second Edition. New York: Longman.

Fraenkel, Jack R. et al. (2012). How to Design and Evaluate Research in Education. New York: McGrawHill.

Kelly, Spencer D. et al. (2008). Gesture Gives a Hand to Language and Learning: Perspectives from Cognitive Neuroscience, Developmental Psychology and Education. Colgate University: Blackwell Publishing Ltd.

Mackey A. and Gass. M Susan. (2005). Second Language Research Methodology and Design. New Jersey: Lawrence Erlbaum Associates, Publisher.

Maria Szott and Megan Molitoris. (2010). How Can Whole Brain Teaching Impact Our Classroom Environment?.

National Research Council. (2004). Engaging Schools Fostering High School Students' Motivation to 
Learn. Washington, D.C.: The National Academies Press.

Panesso, Carmen Helena Rodas et al. (2012). Implementation of The Whole Brain Teaching Method in A Third Grade from A Public School in Pereira, Risaralda. Pereira: Universidad Tecnològica De Pereira.

Qian, Xiaoqing. (2012). A Study on the Teaching Methods of Improving Students' Oral English. Finland: Academy Publisher.

Septiana, Mega. (2014). Somatic Auditory Visual Intellectual (SAVI) in Teaching Speaking of Descriptive Text to the Seventh Grade Students of SMPN 1 Barat Magetan in Schooling Year 2013/2014. Unpublished Thesis. Madiun: Department of English Teaching. IKIP PGRI Madiun.

Westwood, Peter S. (2004). Learning and Learning Difficulties A Handbook for Teachers. Victoria: ACER Press.

Yin K. Robert. (2011). Qualitative Research from Start to Finish. United States of America: The Guild Ford Press. 